Journal of Maternal and Child Health (2017), 2(3): 270-283

https://doi.org/10.26911/thejmch.2017.02.03.08

\title{
Factors Affecting Infant Formula Feeding in Infants Aged o-6 Months in Sukoharjo, Central Java
}

\author{
Ayunda Yonik Nuralita'), Bhisma Murti'1), Eti Poncorini Pamungkasari²) \\ 1) Master Program in Public Health, Sebelas Maret University \\ 2) Department of Public Health, Faculty of Medicine, Sebelas Maret University
}

\begin{abstract}
Background: Formula feeding in infants aged o-6 months may increase the risk of morbidity and mortality. Formula feeding in Indonesia continues to increase from 15\% in 2003 to $79.8 \%$ in 2013. To the best of the authors' knowledge no studies have been done that analyzed the effects of constructs in Theory of Planned Behavior (TPB) on formula feeding practice. This study aimed to analyze the factors influencing formula feeding practice among lactating mothers for their infants aged o-6 months, using TPB constructs.

Subjects and Method: This study was an analytic observational with cross-sectional approach. It was carried out in Sukoharjo District, Central Java, from April to May 2017. A sample of 150 lactating mothers were selected for this study by cluster random sampling. The exogenous variables were the role of health workers, the role of mass media, subjective norm, and maternal education. The endogenous variables were attitudes toward formula feeding, perceived behavioral control, intention, family income, maternal employment status, and formula feeding practice. The data were collected by a set of questionnaire and analyzed by path analysis.

Results: Infant formula feeding was directly affected by maternal intention $(b=1.96 ; 95 \% \mathrm{CI}=0.59$ to $3.34 ; \mathrm{p}=0.005)$, perceived behavior control $(\mathrm{b}=2.24 ; 95 \% \mathrm{CI}=0.79$ to $3.68 ; \mathrm{p}=0.002)$, family income $(b=1.99 ; 95 \% \mathrm{CI}=0.39$ to $3.59 ; \mathrm{p}=0.014)$, and maternal employment status $(\mathrm{b}=-2.01 ; 95 \%$ $\mathrm{CI}=-3.82$ to $-0.21 ; \mathrm{p}=0.029)$. Mother's intention was influenced by her attitude $(\mathrm{b}=1.85 ; 95 \%$ $\mathrm{CI}=0.58$ to $3.12 ; \mathrm{p}=0.004)$, subjective norm $(\mathrm{b}=2.98 ; 95 \% \mathrm{CI}=-0.07$ to $6.04 ; \mathrm{p}=0.056)$, perceived behavior control ( $\mathrm{b}=1.53$; $95 \% \mathrm{CI}=0.44$ to $2.62 ; \mathrm{p}=0.006)$, and mass media $(\mathrm{b}=2.01 ; 95 \% \mathrm{CI}=0.35$ to $3.68 ; \mathrm{p}=0.018)$. Maternal employment status was influenced by maternal education $(b=2.68$; $95 \%$ CI $=1.81$ to $3.55 ; \mathrm{p}<0.001)$. Family income was affected by maternal employment status ( $b=2.10 ; 95 \% \mathrm{CI}=1.24$ to $2.97 ; \mathrm{p}<0.001)$. Maternal attitude was influenced by the role of health personnel $(b=2.73 ; 95 \% \mathrm{CI}=0.68$ to $4.78 ; \mathrm{p}=0.009)$. Likewise, maternal perceived behavior control was influenced by the role of health personnel $(b=1.03 ; 95 \% \mathrm{CI}=0.22$ to $1.84 ; \mathrm{p}=0.013)$.

Conclusion: Infant formula feeding is directly affected by maternal intention, perceived behavior control, family income, and maternal employment status. Infant formula feeding is indirectly affected by attitude, subjective norm, and the role of health personnel.
\end{abstract}

Keywords: formula feeding, theory of planned behavior, infant

\section{Correspondence:}

Ayunda Yonik Nuralita. Masters Program in Public Heath, Sebelas Maret University, Jl. Ir. Sutami 36 A, Surakarta, Central Java. Email: ayundayonik91@gmail.com. Mobile: +6285642477205.

\section{BACKGROUND}

Formula according to Permenkes RI No. 39,2013 is a milk specifically formulated as a replacement for breast milk for infants up to 6 months, but in fact more and more mothers are feeding formula before the baby is 6 months old. (Menkes RI, 2013; Fitriani et al., 2015).
Formula feeding is not recommended for infants aged 0-6 months, as it can increase the risk of morbidity and even death. UNICEF states that the provision of supplemental formulas can increase as much as 25 times of infant mortality early in life (Nurmawati et al, 2015). 
Formula feeding in normal infants aged 0-6 months can adversely affect infants which can increase the risk of otitis media, respiratory infections, allergies, gastro-enteritis, diarrhea, pneumonia, type 1 and type 2 diabetes, cancer risk of leukemia, sudden infant death syndrome, decrease cognitive development in children, and increase the risk of obesity (McNiel et al., 2010; Bonia et al., 2013; UNICEF, 2015; Pries et al., 2016).

Formula may be given to infants younger than 6 months under certain conditions such as infants born less than 2,500 grams, infants treated in incubators, infants with labor trauma, infections, and congenital abnormalities, maternal conditions with swelling, breast abscess, malnutrition, HIV, etc. (Biro et al., 2011). Infant formula feeding has been regulated in the Permenkes RI. 39, 2013 (Menkes RI, 2013).

Globally, in 2008 to 2013 , formula sales increased by $40.8 \%$ from 5.5 to $7.8 \mathrm{~kg}$ / baby / child / year. It is estimated that it will increase to $10.8 \mathrm{~kg}$ in 2018. Sales of formula in Asia have increased, such as in China, Indonesia, Malaysia, Vietnam and Thailand having high infant populations. Baby food sales in the Middle East and North Africa are increasing by $11.2 \%$ during 2007-2012 (Kent, 2015; Baker et al., 2016).

The use of formula in Indonesia had increased in 2003 by $15 \%$ to $79.8 \%$ in 2013 . The percentage of formula usage in Central Java is quite high around $89 \%$ and is ranked in sixth of all provinces in Indonesia. Percentage of formula uses in Sukoharjo District has no data for sure, and when it is seen from percentage of exclusive breastfeeding coverage, the use of formula in Sukoharjo District is high. Coverage of Exclusive ASI in Sukoharjo District increased from $54.7 \%$ in 2014 to $60.4 \%$ in 2015 (MoH RI, 2014; DKK Sukoharjo,
2015; Fitriani et al, 2015; DKK Sukoharjo, 2016).

A mother in taking decision to give formula to her baby is influenced by factors such as mother's last education, income, employment status, and the role of mass media, and health care (Huang et al, 2013; Parry et al, 2013). Another factor that may affect a mother's behavior is included in the theory of planned behavior (Ajzen, 1991).

The research on factors affecting infant formula feeding was done by Puspitasari (2012) showed that the level of education, occupation, income, and knowledge of mothers could influence maternal decisions. Similar research was conducted by Nurmawati et al. (2015) that knowledge, employment status, family income, mother attitudes, health care support, and family support affected the delivery of formula.

\section{SUBJECT AND METHOD \\ 1. Study Design \\ The type of this study was a quantitative research. The study design was analytic observational with cross sectional approach. This study was conducted at Baki, Gatak, and Grogol district Sukoharjo and implemented from April to May 2017.}

\section{Population and Sampling}

The population in this study was mothers who breastfed with formula and mothers who only provided formula to their infants aged o-6 months. The samples in this study were 150 subjects. The sampling technique used was cluster random sampling. The inclusion criteria of the baby were born normally or in Sectio Caesaria (SC), no defects or abnormalities in the infant, and the mother was in good health.

\section{Study Variables}

There were ten variables in this study consisting of endogenous and exogenous variables. Endogenous variables were attitude, intention, and formula feeding. 
Journal of Maternal and Child Health (2017), 2(3): 270-283

https://doi.org/10.26911/thejmch.2017.02.03.08

Exogenous variables are education level, income level, employment status, role of mass media, role of health worker, subjective norm, and perception of behavior control.

\section{Operational Definition}

The income level was defined as the average amount of fixed income (money) and unfixed income from the mother and father (if they are working) per month. The level of education was defined as the level of formal education that was last completed or pursued by the subject of research. Work was defined as the job status of the research subject.

The role of mass media was defined as exposure to the information and promotion of infant formula obtained from the mass media. The role of health personnel was the provision of information, promotion of formula and the actions of health workers who provide formula to newborns without any indication.

Attitude was the response of one's feelings about formula feeding; the subjective norm is the belief in the perceived social pressure of formula feeding; perception of behavior control was perception of control of individual behavior toward formula feeding; intention was an estimation of how likely to display a behavior that signifies whether or not the individual's planning intentions and efforts to try to show formula feeding behavior; and formula feeding behavior was defined as the behavior of study subjects in infant formula feeding for infants aged o-6 months.

\section{Study Instruments}

The instrument of this study used closed questionnaire developed by the researchers based on the existing theory then tested the reliability. Based on the result of the reliability test, the result of measurement of attitude, subjective norm, perception of behavioral control, intention, role of mass media, and the role of health worker with total item chore value was $\geq 0.20$ and alpha Cronbach was $>0.60$, so that all the questions are reliable.

\section{Data Analysis}

Univariate analysis was used to present data on the subject of research subjects and descriptions of research findings. Bivariate analysis was used to analyze the influence of independent variable to dependent variables using chi-square test. Path analysis was used to analyze the exogenous variables of variables on endogen variables through intermediate variables. The steps of path analysis were:

1. Model specification

2. Model identification

3. Model fit

4. Parameter estimation

5. Model respecification

\begin{tabular}{lllll}
\hline \multicolumn{5}{c}{ RESULTS } \\
\hline Table 1 shows that of the 150 study
\end{tabular} subjects, most mothers aged 27-36 years were 74 subjects (49\%) and the lowest were 37-46 years old as many as 16 subjects (11.0\%).

The study subjects with Senior High School education attainment or higher were 107 subjects (71.3\%) and those with lower than Senior High School were 43 subjects (28.7\%). As many as 94 subjects (62.7\%) worked and 56 subjects (37.3\%) did not work. The study subjects with family income equal or above Regional Minimum Wage (UMR) were 115 subjects (76.7\%), and those with family income less than UMR were 35 subjects (23.3\%).

Table 3 shows that all the independent variables have a positive influence on the formula feeding behavior. The greatest influence was given by the perception of behavioral control $(\mathrm{OR}=16.77$; 95\% CI = 4.41 to 63.75 ; $\mathrm{p}<0.001)$. The weakest effect 
was given by maternal employment status which showed almost no effect on formula feeding behavior $(\mathrm{OR}=0.39 ; 95 \% \mathrm{CI}=0.10$ to $1.43 ; \mathrm{p}=0.143)$. Reliable findings consist

Table 1. Characteristics of research subjects

\begin{tabular}{llcc}
\hline \multicolumn{1}{c}{ Characteristic } & \multicolumn{1}{c}{ Category } & n & \% \\
\hline Age (Year) & 17-26 years Old & 60 & 40.0 \\
& 27-36 Years Old & 74 & 49.0 \\
Mother's Education & 37-46 Years Old & 16 & 11.0 \\
& Low (<Senior High School) & 43 & 28.7 \\
Maternal's Job Status & High ( $\geq$ Senior High School) & 107 & 71.3 \\
Family Income & Unemployment & 56 & 37.3 \\
& Working & 94 & 62.7 \\
& Low (<Regional Minimum Wage) & 35 & 23.3 \\
\hline
\end{tabular}

Table 2. Univariate analysis of research variables

\begin{tabular}{llcc}
\hline \multicolumn{1}{c}{ Variable } & \multicolumn{1}{c}{ Category } & Frequency (n) & Percentage (\%) \\
\hline Attitude & Negative & 17 & 11.3 \\
Subjective Norm & Positive & 133 & 88.7 \\
& Low & 4 & 2.7 \\
Behavioral Control Peception & High & 146 & 97.3 \\
& Low & 38 & 25.3 \\
Intention & High & 112 & 74.7 \\
\multirow{3}{*}{ Role of Mass Media } & Weak & 22 & 14.7 \\
\multirow{3}{*}{ Role of Health Worker } & Strong & 128 & 85.3 \\
& Low & 96 & 64.0 \\
& High & 54 & 36.0 \\
& Low & 84 & 56.0 \\
\hline
\end{tabular}

Table 2 shows that each variable has a different distribution. Description of research variables is explained by characteristics, criteria, frequency, and percentage (\%). The results of descriptive statistics of of family representation, attitudes, perceptions of behavioral control, and intentions because they have $\mathrm{p}<0.05$.

Table 3. Bivariate analysis of Chi Square test on the influence of independent variables on infant formula feeding in infants aged o-6 months

\begin{tabular}{|c|c|c|c|c|}
\hline \multirow{2}{*}{ Independent Variable } & \multirow{2}{*}{ OR } & \multicolumn{2}{|c|}{$95 \% \mathrm{CI}$} & \multirow[b]{2}{*}{$\mathbf{p}$} \\
\hline & & Lower & Upper & \\
\hline Mother's education ( $\geq$ SMA) & 0.59 & 0.16 & 2.22 & 0.434 \\
\hline Maternal's job status (Working) & 0.39 & 0.10 & 1.43 & 0.143 \\
\hline Family income ( $>$ UMR) & 3.34 & 1.12 & 10.01 & 0.024 \\
\hline Attitude (positive) & 5.12 & 1.50 & 17.47 & 0.005 \\
\hline Subjective norma (high) & 3.14 & 0.30 & 32.28 & 0.311 \\
\hline Behavioral conrol perception (high) & 16.77 & 4.41 & 63.76 & $<0.001$ \\
\hline Intention (strong) & 9.88 & 3.11 & 31.37 & $<0.001$ \\
\hline Role of mass media (high) & 4.07 & 0.88 & 18.78 & 0.054 \\
\hline Role of health worker (high) & 2.33 & 0.71 & 7.70 & 0.154 \\
\hline
\end{tabular}




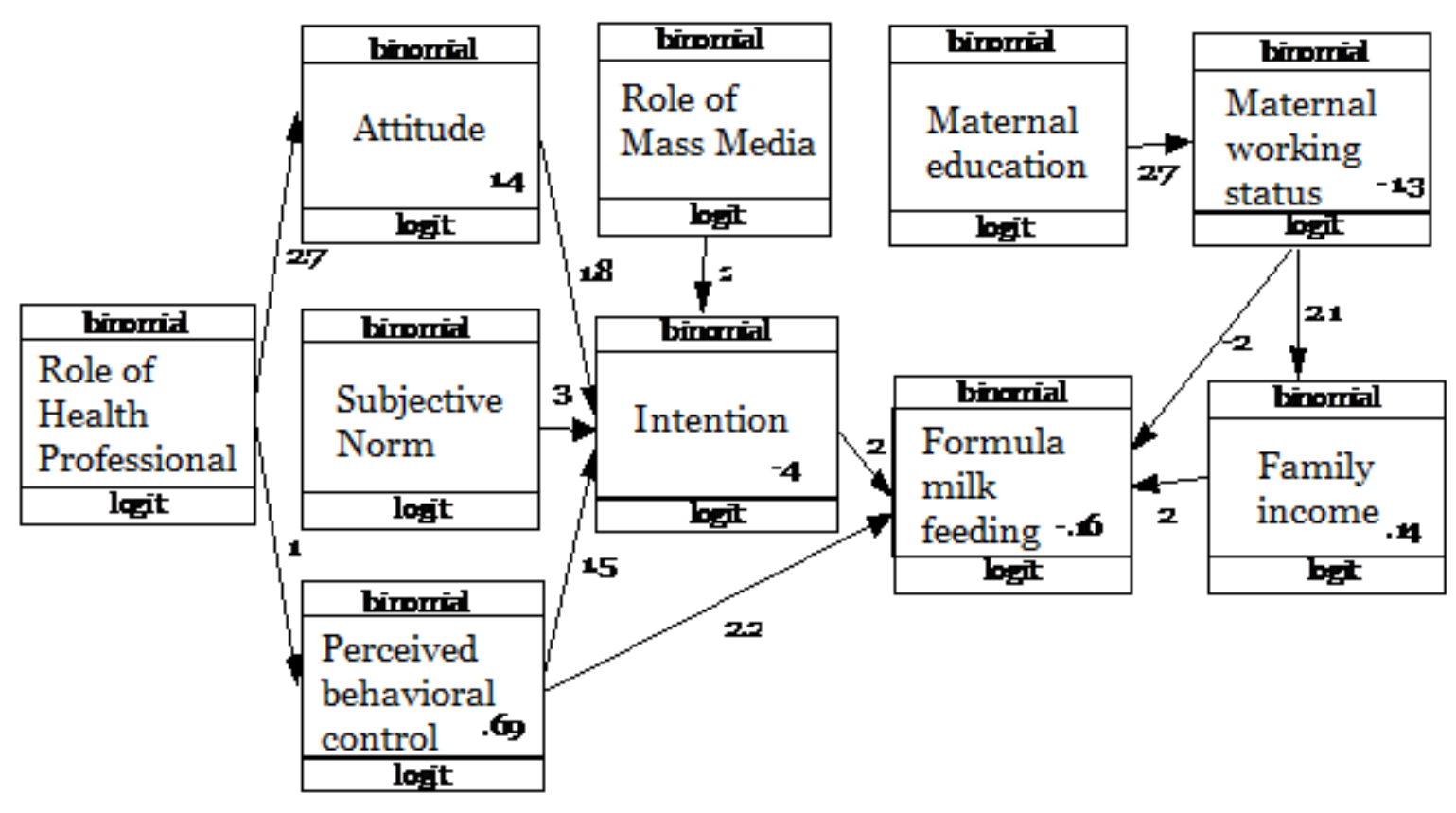

Figure 1. Structural Model of Path Analysis

Figure 1 shows the structural model after the estimation used the IBM SPSS STATA 13, so it was obtained a value as in the figure.

Through Table 4 it can be seen that formula feeding is directly influenced by intentions, perceptions of behavior control, maternal employment status, and family income.

Mothers with strong intentions had a log odd average of 1.96 points higher for infant formula feeding than mothers with weak intentions $(b=1.96 ; 95 \% \mathrm{CI}=0.59$ to 3.34; $\mathrm{p}=$ 0.005). Mothers with high behavioral perception controls had a log odd average of 2.24 points higher for infant formula feeding than mothers with low behavioral control perceptions $(b=2.24$; $95 \% \mathrm{CI}=0.79$ to $3.68 ; \mathrm{p}=0.002$ ). Mothers with high family incomes had a $\log$ odd average of 1.99 points higher for infant formula feeding than mothers with low family income $(\mathrm{b}=1.99 ; 95 \% \mathrm{CI}=0.39$ to 3.59; $\mathrm{p}=0.014)$. Working mothers had a log odd average of 2.01 points lower for infant formula feeding than unemployed mothers $(\mathrm{b}=-2.01 ; 95 \% \mathrm{CI}=-3.82$ to $0.21 ; p=0.029)$.

Intention is influenced by mother's attitude, subjective norm, perception of behavior control and role of mass media. Mothers with a positive attitude had a log odd average of 1.85 points higher to have strong intentions than mothers with a negative attitude $(\mathrm{b}=1.85 ; 95 \% \mathrm{CI}=0.58$ to $3.12 ; \mathrm{p}=0.004)$. Mothers with high subjective norms had a log odd average of 2.98 points higher for strong intentions than mothers with low subjective norms (b $=2.98 ; 95 \% \mathrm{CI}=-0.07$ to $6.04 ; \mathrm{p}=0.056)$. Mothers with high perceptions of behavioral control had a log odd average of 1.53 points higher for strong intentions than mothers with low perception of behavioral control $(b=1.53$; $95 \% \mathrm{CI}=0.44$ to $2.62 ; \mathrm{p}=$ o.006). Mothers with high mass media roles have a log odd average of 2.01 points higher to have strong intentions than mothers with low mass media roles $(\mathrm{b}=$ 2.01; 95\% CI $=0.35$ to $3.68 ; \mathrm{p}=0.018$ ) .

The status of maternal job is influenced by the mother's education level. 
Mothers with high education had a log odd average of 2.68 points higher for employment opportunities than mothers with low education $(\mathrm{b}=2.68 ; 95 \% \mathrm{CI}=1.81$ to 3.55 ; $\mathrm{p}<0.001)$.

Table 4. Path analysis of the factors influencing the behavior of formula feeding

\begin{tabular}{|c|c|c|c|c|c|c|}
\hline \multirow[b]{2}{*}{$\begin{array}{l}\text { Dependent } \\
\text { Variables }\end{array}$} & & \multirow[b]{2}{*}{$\begin{array}{c}\text { Independent } \\
\text { Variables }\end{array}$} & \multirow{2}{*}{$\begin{array}{c}\text { Path } \\
\text { Coefficient }\end{array}$} & \multicolumn{2}{|c|}{ 95\%CI } & \multirow[b]{2}{*}{$\mathbf{p}$} \\
\hline & & & & $\begin{array}{l}\text { Lower } \\
\text { Limit }\end{array}$ & $\begin{array}{l}\text { Upper } \\
\text { Limit }\end{array}$ & \\
\hline \multirow{5}{*}{$\begin{array}{l}\text { Direct Effect } \\
\text { Formula feeding } \\
\text { (feeding) }\end{array}$} & & & & & & \\
\hline & $\leftarrow$ & $\begin{array}{l}\text { Maternal intention } \\
\text { (strong) }\end{array}$ & 1.96 & 0.59 & $3 \cdot 34$ & 0.005 \\
\hline & & $\begin{array}{l}\text { Perceived behavioral } \\
\text { control (high) }\end{array}$ & 2.24 & 0.79 & 3.68 & 0.002 \\
\hline & $\leftarrow$ & $\begin{array}{l}\text { Family income } \\
\text { ( } \geq \text { regional minimum } \\
\text { wage) }\end{array}$ & 1.99 & 0.39 & 3.59 & 0.014 \\
\hline & $\leftarrow$ & $\begin{array}{l}\text { Status of maternal's } \\
\text { job (working) }\end{array}$ & -2.01 & -3.82 & -0.21 & 0.029 \\
\hline \multirow{5}{*}{$\begin{array}{l}\text { Indirect Effect } \\
\text { Maternal intention } \\
\text { (strong) }\end{array}$} & & & & & & \\
\hline & $\leftarrow$ & $\begin{array}{l}\text { Mother's attitude } \\
\text { (positive) }\end{array}$ & 1.85 & 0.58 & 3.12 & 0.004 \\
\hline & $\leftarrow$ & $\begin{array}{l}\text { Maternal subjective } \\
\text { norm (high) }\end{array}$ & 2.98 & -0.07 & 6.04 & 0.056 \\
\hline & $\leftarrow$ & $\begin{array}{l}\text { Perception of } \\
\text { mother's behavioral } \\
\text { control (high) }\end{array}$ & 1.53 & 0.44 & 2.62 & 0.006 \\
\hline & $\leftarrow$ & $\begin{array}{l}\text { Role of mass media } \\
\text { (high) }\end{array}$ & 2.01 & 0.35 & 3.68 & 0.018 \\
\hline $\begin{array}{l}\text { Status of maternal } \\
\text { job (working) }\end{array}$ & $\leftarrow$ & $\begin{array}{l}\text { Mother's education } \\
\text { ( } \geq \text { senior high school) }\end{array}$ & 2.68 & 1.81 & 3.55 & $<0.001$ \\
\hline $\begin{array}{l}\text { Family income } \\
\text { ( }>\text { regional } \\
\text { minimum wage) }\end{array}$ & $\leftarrow$ & Mother is working & 2.10 & 1.24 & 2.97 & $<0.001$ \\
\hline $\begin{array}{l}\text { Mother's attitude } \\
\text { (positive) }\end{array}$ & $\leftarrow$ & $\begin{array}{l}\text { Role of heaLth } \\
\text { worker (high) }\end{array}$ & 2.73 & 0.68 & 4.78 & 0.009 \\
\hline $\begin{array}{l}\text { Perception of } \\
\text { maternal behavioral } \\
\text { control (high) }\end{array}$ & $\leftarrow$ & $\begin{array}{l}\text { Role of health worker } \\
\text { (high) }\end{array}$ & 1.03 & 0.22 & 1.84 & 0.013 \\
\hline Log Possibility & $=$ & -349.11 & & & & \\
\hline $\mathrm{AIC}$ & $=$ & 734.22 & & & & \\
\hline BIC & $=$ & 788.41 & & & & \\
\hline
\end{tabular}

Mother's income is influenced by mother's job. Working mothers had a log odd average of 2.10 points higher for highnincome than unemployed mothers (b $=2.10 ; 95 \% \mathrm{CI}=1.24$ to $2.97 ; \mathrm{p}<0.001$ ).

Mother's attitude is influenced by the role of health worker. The mothers affected by high health personnel had an log odd average of 2.73 points higher for a positive attitude than mothers who had the effect of low-skilled health personnel $(\mathrm{b}=2.73 ; 95 \%$ $\mathrm{CI}=0.68$ to $4.78 ; \mathrm{p}=0.009$ ).

Perceptions of behavior control are influenced by the role of health personnel. Mothers affected by high health workers had a log odd average of 1.03 points higher to have a higher perception of behavioral control than mothers affected by lowskilled health workers $(\mathrm{b}=1.03 ; 95 \% \mathrm{CI}=$ 0.22 to $1.84 ; \mathrm{p}=0.01$ ).

\section{DISCUSSION}


Journal of Maternal and Child Health (2017), 2(3): 270-283

https://doi.org/10.26911/thejmch.2017.02.03.08

\section{Influence of Mother's Intention to the Formula Feeding}

The results of path analysis show that there is a positive influence between maternal intentions and formula feeding behavior. Mothers with strong intentions had a log odd average of 1.96 points higher for formula feeding than mothers with weak intentions. The results showed that mothers with strong intentions were 1.96 times more likely to give infant formula and were statistically significant $(b=1.96$; 95\% $\mathrm{CI}=0.59$ to $3.34 ; \mathrm{p}=0.005$ ).

Theory of Planned Behavior (TPB) explains that the behavior of each individual depends on the intention. The stronger the intention of a person is, the more likely the behavior will be done (Ajzen, 1991). Intention is the motivation and conscious view of a person in making a plan by giving up all efforts to be able to carry out certain behaviors (Maichum, 2016).

Based on the results, it can be concluded that the strength and weakness of a mother's intention associated with the behavior of formula feeding. Strong intentions can increase the behavior of infant formula feeding.

\section{The Influence of Perception of Mother's Behavioral Control toward Formula Feeding Behavior}

The result of path analysis shows that there is a positive influence between the perception of mother's behavior control and formula feeding behavior. Mothers with high behavioral perception controls had a log odd average of 2.24 points higher for formula feeding than mothers with low perception of behavioral control. The results of this analysis indicate that mothers with a high perception of behavioral control are 2.24 times more likely to provide infant formula. Statistically the results are significant $(\mathrm{b}=2.24 ; 95 \% \mathrm{CI}=$ 0.79 to $3.68 ; \mathrm{p}=0.002$ ).
The perception of behavior control is a non-motivated factor in the availability of necessary opportunities and resources such as money, time, skills and cooperation, and an individual's perception of the ease or difficulty of performing a behavior (Ahmad et al., 2016). The perception of high maternal behavior control indicates that the mother feels easy to perform a behavior, referred to in this research, is the behavior of infant formula feeding (Ajzen, 1991).

Based on the above, it can be concluded that the height of the perception of a mother's behavioral control is related to the behavior of formula feeding. Perception of high behavioral control can increase the behavior of infant formula feeding.

\section{The Influence of Family Income on Feeding Behavior Formula}

Path analysis result shows that there is a positive influence between family income and formula feeding behavior. Mothers with high family incomes had a $\log$ odd average of 1.99 points higher for formula feeding than mothers with low family income. The results of the analysis indicate that mothers with high family incomes were 1.99 times more likely to give formula milk. The results are statistically significant so that the findings are reliable $(b=1.99 ; 95 \%$ $\mathrm{CI}=0.39$ to 3.59 ; $\mathrm{p}=0.014$ ).

The results of this study are consistent with the study of Nurmawati et al. (2015) which suggested that subjects with high family incomes would tend to prefer to provide infant formula to their infants rather than research subjects with low family income. As many as $84.6 \%$ had high family income and provide formula.

Research conducted by Hong (2015) also mentioned that income could affect a mother to buy and provide formula for her baby or her children. As many as $89.3 \%$ of research subjects with high incomes tended 
to buy and provided infant formula to their infants compared to low-income research subjects.

Based on the above, it can be concluded that family income level is related to formula feeding behavior. High family income can increase the purchase of infant formula and infant formula.

\section{The Influence of Maternal Job Status to the Formula Feeding Behavior}

The result of path analysis shows that there is a negative influence between maternal job status and formula feeding behavior. Working mothers had a log odd average of 2.01 points lower for formula feeding than unemployed mothers. The results of the analysis show that working mothers had 2.01 times less chance of feeding formula. Statistically the results are significant so that the findings are reliable $(b=-2.01$; $95 \% \mathrm{CI}=-3.82$ to $-0.21 ; \mathrm{p}=0.029)$.

The results of this study are not in accordance with the research that had been done by Isnaini and Apriyanti (2015) which showed that working mothers at risk 7 times greater to provide formula compared with mothers who do not work ( $\mathrm{OR}=7.00)$. Research conducted by Ijaz et al. (2015) also mentioned that as many as 11 out of 16 study subjects (57.9\%) working mothers preferred to provide formula rather than breastfeeding.

For working mothers, exclusive breastfeeding efforts often experience obstacles because of the short duration of maternity leave and frequent reasons to exclude exclusive breastfeeding and replace it with formula, especially those living in urban areas (Agam et al., 2012).

Based on the above discussion, it can be concluded that the status of maternal's job is related to formula feeding behavior. In theory, working mothers are more likely to give formula than unemployed mothers, but in this study the status of job and formula feeding had an inverse relationship (negative) in which working mothers can decrease the infant formula. This negative relationship could occur because mother's might during the house be diligent of pumping breastmilk to be stored and given to the baby while the mother was at work, beside the office where mother's working has been supporting breastfeeding by providing a room for mothers can pump or squeeze milk.

\section{The Influence of Mother's Attitude on Mother's Intention}

The result of path analysis shows that there is a positive influence between mother's attitude and mother's intention. Mothers with a positive attitude had a log odd average of 1.85 points higher to have strong intentions than mothers with a negative attitude. The results of the analysis indicated that mothers with positive attitudes were 1.85 times more likely to have strong intentions of formula feeding. Statistically the results were significant so that the findings were reliable $(b=1.85$; $95 \% \mathrm{CI}=0.58$ to $3.12 ; \mathrm{p}=0.004$ ).

Attitude is one of the factors included in the theory of health behavior is Theory of Planned Behavior (TPB). Attitudes are portrayed as positive or negative feelings to perform a behavior, but the behavior of each individual also depends on intention. The more positive the attitude, the stronger the intention, and ultimately a person will be more likely to perform a behavior (Ajzen, 1991). Intention is the motivation and the conscious view of a person in making a plan by splitting all efforts to be able to carry out certain behaviors (Maichum, 2016).

Based on the above, it can be concluded that mother's attitude is related to formula feeding behavior through intention. Mothers who have a positive attitude 
Journal of Maternal and Child Health (2017), 2(3): 270-283

https://doi.org/10.26911/thejmch.2017.02.03.08

can increase or strengthen the mother's intention to provide infant formula.

\section{The Influence of Maternal Norms on Mother's Intention}

The result of path analysis shows that there is a positive influence between subjective norm mother and mother's intention. Mothers with high subjective norms had a log odd average of 2.98 points higher to have strong intentions than mothers with low subjective norms. The results of the analysis indicated that mothers who had high subjective norms are more likely to have strong intentions to provide formula milk. Statistically the results are significant so that the findings are reliable $(b=2.98$; 95\% CI $=-0.07$ to $6.04 ; \mathrm{p}=0.056$ ).

The subjective norm reflects social influences and is described as a person's perception of performing or not performing a behavior. Theory of Planned Behavior explains that subjective norms can influence the occurrence of a behavior through intention, where the higher the subjective norm, the stronger the intention of a person to perform a behavior (Ajzen, 1991).

A person who has an idea that what will be done is appropriate, acceptable to the environment, and will receive positive feedback, as well as the attention of others, will enhance and strengthen the intention to perform certain behaviors (Ajzen, 1991; et al., 2016).

Based on this matter, it can be concluded that subjective norm of mother related to behavior of formula feeding through intention. Mothers who have high subjective norms can increase or strengthen the mother's intention to provide infant formula.

\section{The Influence of Mother's Percep- tion Control of Mother's Intention}

The result of path analysis shows that there is a positive influence between the perception of mother's behavior control and mother's intention. Mothers with high behavioral perception controls had a log odd average of 1.53 points higher for strong intentions than mothers with low perception of behavioral control. The results of the analysis indicate that mothers with high perception of behavioral control are more likely to have strong intentions to provide infant formula. Statistically the results are significant so that the findings are reliable $(b=1.53 ; 95 \% C I=0.44$ to $2.62 ; p=0.006)$.

The results of this study are in accordance with a study conducted by Tarrant et al. (2013) which suggested that a positive maternal percentage of formula feeding is one of the most frequent reasons underlying maternal decisions on infant formula feeding.

The perception of behavioral control refers to a person's perception of how easy or difficult it is to perform a particular behavior. The perception of high maternal behavior control indicates that the mother feels easy to perform a behavior, so that mother will have strong intention to conduct a behavior, where the behavior referred to in this research is the behavior of infant formula feeding. Perceptions of behavioral control have been shown to have an effect on the relationship between intention and one's behavior (Ajzen, 1991, Ahmad et al, 2016).

Based on the above discussion, it can be concluded that the high perception of maternal behavior control is related to formula feeding behavior through the weakness of mother's intention. High perception of behavior control can reinforce the intentions of mothers so she tends to prefer to provide infant formula.

\section{The Influence of Mass Media Role on Mother's Intention}


The result of path analysis shows that there is a positive influence between the role of mass media and mother's intention. Mothers with high mass media roles had a log odd average of 2.01 points higher to have strong intentions than mothers with low mass media roles. The results of this analysis indicate that mothers with a high role of mass media have a greater possibility of having a strong intention to feed the formula and are statistically significant $(\mathrm{b}=2.01 ; 95 \% \mathrm{CI}=0.35$ to $3.68 ; \mathrm{p}=$ 0.018).

The results of this study are in accordance with a study conducted by Sahusila-wane et al., (2013) showed that there was a relationship between media exposure and PASI $(\mathrm{OR}=0.29 ; \mathrm{p}=0.048)$. Mothers with high media exposure (often informed by the media) had a higher probability of 0.298 to provide PASI than mothers with low exposure to media (rarely getting information from the media).

Research conducted by Lokare et al. (2016) also showed that the increase in formula consumption in infants was influenced by mass media and the ease of accessing the internet. Increasing the ad campaign of formula products in the mass media causes the mother's purchasing power to increase and then prefer to give formula to the baby so that give negative effect to breastfeeding decreasing (Stevens et al, 2009).

Based on this matter, it can be concluded that the role of mass media is related indirectly to formula feeding behavior through mother's intention. The higher a mother exposed by the media, the more it can improve and strengthen the intention of mothers to tend to prefer to give formula to the baby.

9. The Influence of Mother's Education on Mother's Employment Status
The result of path analysis shows that there is a positive influence between mother education and maternal job status. Mothers with a high education had a log odd average of 2.68 points higher to have employment opportunities than mothers with low education. The results of the analysis indicate that mothers with a higher education are more likely to work outside the home and are statistically significant $(b=2.68 ; 95 \%$ $\mathrm{CI}=1.81$ to $3.55 ; \mathrm{p}<0.001$ )

Mothers with high education have a greater and easier chance of getting a job outdoors, which will encourage mothers to prefer to give formula compared to unemployed mothers (Ali, 2009).

The results of this study are consistent with the research conducted by Isnaini and Apriyanti (2015) indicated that there is a relationship between maternal employment status and formula feeding behavior $(\mathrm{OR}=$ 7.00), where working mothers are 7 times more likely to provide infant formula than a unemployment mothers.

Based on the above, it can be concluded that education is indirectly related to the formula feeding behavior through the mother's job status. High maternal education can make it easier for mothers to work outside the home so will tend to prefer to give formula to the babies.

\section{The Influence of Mother's Em- ployment Status to Family Income}

The result of path analysis shows that there is a positive influence between maternal job status with family income. Working mothers have a log odd average of 2.10 points higher for high income than unemployed mothers. The results of the analysis indicate that mothers working outside the home are more likely to have higher family income and are statistically significant $(b=2.10 ; 95 \% \mathrm{CI}=1.24$ to 2.97 ; $\mathrm{p}<0.001)$. 
Journal of Maternal and Child Health (2017), 2(3): 270-283

https://doi.org/10.26911/thejmch.2017.02.03.08

The results of this study are consistent with studies conducted by Agam et al., (2012) showed that families with high incomes are more likely to feed infant formula than breast milk than low income families. A study conducted by Kumalasari et al. (2015) showed that working mothers had 1.91 risks of providing breastfeeding to infants $<6$ months old and also showed that higher family income enabled mothers to deliver early breastfeeding.

Mothers with a high education are more likely to find employment and have higher family incomes that will encourage mothers to prefer formula feeding than those with low family incomes (Ali, 2009). The better the economy of a family, the higher the purchasing power of the family will be (Kumalasari et al, 2015).

Based on the discussion above, it can be concluded that the status of the mother's job is indirectly related to the behavior of formula feeding through family income. Working mothers are more likely to have high family income so it will tend to prefer to give infant formula.

\section{The Influence of Health Worker's Role to Mother's Attitude}

The result of path analysis shows that there is a positive influence between the role of health worker and mother's attitude. Mothers who are affected by high health workers have a log odd average of 2.73 points higher for a positive attitude than mothers who are affected by low health care workers. The results of the analysis indicate that mothers who are affected by high health workers are more likely to have a positive attitude toward formula feeding. The results are statistically significant so that the findings are reliable $(b=2.73 ; 95 \%$ $\mathrm{CI}=0.68$ to $4.78 ; \mathrm{p}=0.009$ ).

The results of this study are in accordance with research conducted by Nurmawati et al., (2015) stated that health workers have a significant role in infant formula feeding. The more often the health worker suggests formula feeding to infants, the more mothers will tend to give formula milk to their baby.

Attitude is described as a positive or negative evaluation of an individual to perform a behavior. Health workers who frequently recommend formula feeding can influence the mother's attitude to a positive attitude toward formula feeding. This positive attitude will over time generate a strong intention from within the mother, so mothers will finally decide to give formula to her baby (Ajzen, 1991; Ahmad et al., 2016).

Based on the above discussion, it can be concluded that the role of health workers is indirectly related to the formula feeding behavior through the mother's attitude. Mothers who increasingly often get the influence of health workers have a greater possibility of having a positive attitude which will increase and strengthen the intentions of mothers so it will tend to prefer to provide infant formula.

12. The Influence of the Role of Health Personnel on the Perception of Maternal Behavior Control

The result of path analysis shows that there is a positive influence between the role of health worker and the perception of mother's behavior control. Mothers who are affected by high health workers have a log odd average of 1.03 points higher to have a higher perception of behavioral control than mothers who are affected by low health care workers. The results of the analysis indicate that mothers who are affected by high health workers are more likely to have a high perception of behavioral control over formula feeding. The results are statistically significant so that the findings are reliable $(\mathrm{b}=1.03 ; 95 \% \mathrm{CI}=$ 0.22 to $1.84 ; \mathrm{p}=0.013$ ). 
The results of this study are consistent with research conducted by Battersby (2009) showed that many midwives in Poland have poor knowledge, poor or incorrect understanding of infant formula, and lack of support and approach to breastfeeding mothers, so mothers prefer to decide to give formula to their baby.

The perception of behavior control is a non-motivated factor in the availability of necessary opportunities and resources such as money, time, skills and cooperation, and an individual's perception of the ease or difficulty of performing a behavior (Ahmad et al., 2016). A particular behavior occurs when an individual has both factors: the ability and motivation to perform the behavior, but not when the individual has only one factor or none (Maichum, 2016).

One of the things that can give motivation to mother to decide to give formula is from role of health worker. Mothers, who have the financial ability, time and skill, and receive high support from health personnel, will have a high perception of behavior control and can increase or strengthen mother's intentions so that mothers decide to give formula to their baby.

Based on the result of the research, it can be concluded that the role of health worker is indirectly related to the behavior of formula feeding through perception of mother's behavior control. Mothers who increasingly often get the influence of health workers have a greater possibility of having a perception of high behavioral control and can increase or strengthen the intention of mothers so it will tend to prefer to provide infant formula.

\section{REFERENCE}

Agam I, Syam A, Citrakesumasari (2012).

Faktor-Faktor yang Mempengaruhi
Pemberian ASI Eksklusif di Kelurahan Tamamaung Kecamatan Panakkukang Kota Makassar. Program Studi Ilmu Gizi Fakultas Kesehatan Masyarakat UNHAS.

Ahmad MA, Mahmood J, Hussin ARC, Dahlan HM (2016). Review on Previous Constructs Used in Theory of Planned Behavior. Journal of Information Systems Research and Innovation. 10(1) : 22-28.

Ajzen I (1991). The Theory of Planned Behavior. Organizational Behavior and Human Decision Processes. 50(2): 179-211.

Ali M (2009). Pendidikan untuk Pembangunan Nasional : Menuju Bangsa Indonesia yang mandiri dan Berdaya Saing Tinggi. Jakarta: Grasindo.

Baker P, Smith J, Salmon L, Friel S, Kent G, Iellamo A, Dadhich JP, Renfrew MJ (2016). Global Trends and Patterns of Commercial Milk-based Formula Sales: Is an Unprecedented Infant and Young Child Feeding Transition Underway?. Public Health Nutrition. 111.

Battersby S (2009). An Evaluation of Midwives' Knowledge of Formula Feeding and Their Role in Supporting Mothers who Formula Feed Their Infants. Journal of Family Health Care. 20(6): 192-197.

Biro MA, Sutherland GA, Yelland JS, Hardy P, Brown SJ (2011). In-Hospital Formula Supplementation of Breastfed Babies: A Population-Based Survey. Birth Issue in Perinatal Care. 38 (4).

Bonia K, Twells L, Halfyard B, Ludlow V, Newhook LA, Goodridge JM (2013). A Qualitative Study Exploring Factors Associated with Mothers' Decisions to Formula-Feed Their Infants in Newfoundland and Labrador, Canada. BMC Public Health. 13:645. 
DKK Sukoharjo (2015). Profil Kesehatan Kabupaten Sukoharjo Tahun 2014. Dinas Kesehatan Kabupaten Sukoharjo.

DKK Sukoharjo (2016). Profil Kesehatan Kabupaten Sukoharjo Tahun 2015. Dinas Kesehatan Kabupaten Sukoharjo.

Fitriani K, Rahayuning DP, Nugraheni SA (2015). Faktor-Faktor yang Melatarbelakangi Ibu dalam Pemberian Susu Formula pada Bayi Usia o-6 Bulan di Wilayah Kerja Puskesmas Rowosari Kecamatan Tembalang, Semarang. Jurnal Kesehatan Masyarakat (EJournal). 3 (2): 118-126.

Hong PTT (2015). Factors Influencing on Purchasing Formula Milk for Babies: An Empirical Research in Hanoi. International Journal of Business Administration. 6(5) : 37-43.

Huang Y, Wolfe JL, Huang H, Choiniere CJ, Fein SB (2013). Association of Health Profession and Direct to Consumer Marketing with Infant Formula Choice and Switching. Birth Issue in Perinatal Care. 40(1). March 2013.

Ijaz S, Ijaz T, Afzal RK, Afzal MM, Mukhtar $\mathrm{O}$, Ijaz $\mathrm{N}$ (2015). Infants-Feeding Practices and Their Relationship with Socio-Economic and Health Conditions in Lahore, Pakistan. Advancements in Life Sciences Journal. 2(4): 158-164.

Isnaini N, Apriyanti R (2015). FaktorFaktor yang Berhubungan dengan Pemberian Susu Formula pada Bayi Umur o-6 Bulan di BPS Agnes Way Kandis Bandar Lampung Tahun 2013. Jurnal Kebidanan. 1(1): 1-4.

Kemenkes RI (2014). Situasi dan Analisis ASI Eksklusif. Jakarta: Kementerian Kesehatan Republik Indonesia.

Kent G (2015). Global Infant Formula: Monitoring and Regulating the Im- pacts to Protect Human Health. International Breastfeeding Journal. 10(6): 1-12.

Kumalasari SY, Sabrian F, Hasanah O (2015). Faktor-Faktor yang Berhubungan dengan Pemberian Makanan Pendamping ASI Dini. JOM. 2(1): 879-889.

Lokare L, Hippargi A (2016). Qualitative Exploration of Bottle Feeding Practices among Mothers of Dharwad District, Karnataka: A Focus Group Discussion Study. International Journal of Community Medicine and Public Health. 3(1): $90-93$.

Maichum K, Parichatnon S, Peng KC (2016). Application of the Extended Theory of Planned Behavior Model to Investigate Purchase Intention of Green Products among Thai Consumers. Sustainability. 2016, 8, 1077.

McNiel ME, Labbok MH, Abrahams SW (2010). What are the Risks Associated with Formula Feeding? A Re-Analysis and Review. Birth Issue in Perinatal Care. 37(1).

Menkes RI (2013). Peraturan Menteri Kesehatan Republik Indonesia Nomor 39 Tahun 2013 Tentang Susu Formula Bayi Dan Produk Bayi lainnya. Jakarta : Menteri Kesehatan Republik Indonesia.

Nurmawati I, Nugraheni SA, Kartini A (2015). Faktor Determinan Pemberian Susu Formula pada Bayi Usia o-6 Bulan (Studi pada Ibu Bayi Usia 7-12 Bulan di Wilayah Puskesmas Kabupaten Demak). Jurnal Manajemen Kesehatan Indonesia. 03 (01) : 81-90.

Parry K, Taylor E, Dardess PH, Walker M, Labbok M (2013). Understanding Women's Interpretations of Infant Formula Advertising. Birth Issue in Perinatal Care. 40(2). 
Pries AM, Huffman SL, Mengkheang K, Kroeun H, Champeny M, Roberts M, Zehner E (2016). Pervasive Promotion of Breastmilk Substitutes in Phnom Penh, Cambodia, and High Usage by Mothers for Infant and Young Child Feeding. Maternal \& Child Nutrition. 12(2): 38-51.

Puspitasari RI (2012). Gambaran FaktorFaktor yang Mempengaruhi Pemberian Susu Formula pada Ibu yang Mempunyai Bayi Usia o - 6 Bulan di Bidan Praktek Swasta $\mathrm{Hj}$. Renik Suprapti Kelurahan Bantarsoka Kecamatan Purwokerto Barat Kabupaten Banyumas Tahun 2011. Jurnal Ilmiah Kebidanan. 3 (1): 1-17.

Sahusilawane HE, Abdullah HMT, Salmah U (2013). Faktor yang Mempengaruhi Pemberian PASI pada Bayi Usia o-6
Bulan di Wilayah Kerja Puskesmas Christina Martha Tiahahu Kota Ambon Tahun 2013. Bagian Biostatistik/KKB, Fakultas Kesehatan Masyarakat, UNHAS, Makassar.

Stevens EE, Patrick TE, Pickler R (2009). A History of Infant Feeding. The Journal of Perinatal Education. 18(2): 3239.

Tarrant RC, Margaret SP, Roberta AMC, Katherine MY, John M (2013). Mothers who Formula Feed: Their Practices, Support Needs and Factors Influencing Their Infant Feeding Decision. Child Care in Practice Journal. 19(1): 78-94.

UNICEF (2015). Paket Konseling : Pemberian Makan Bayi dan Anak. United Nations International Children's Emergency Fund. 